\title{
Universities in clash over Internet 'libel' allegations
}

London and Montreal. A British academic, stung by a series of personal attacks posted on the Internet, has threatened to sue six North American universities for their part in 'promoting libel'. In what could be the first case of its kind, Laurence Godfrey, a 41year-old London-based physics lecturer, has written to five universities in Canada and one in the United States asking them to censor allegedly libellous messages about him mailed from their campuses to the user group Usenet.

Godfrey, who worked as a high-energy physicist for the National Research Council (NRC) of Canada between 1984 and 1992, says universities must bear responsibility for electronic mail passing through their computer terminals. "Universities think I am threatening freedom of speech. But what about the damage done to my reputation?"

$\mathrm{He}$ claims that the material transmitted "has lowered my esteem in the eyes of students, colleagues and future colleagues". Godfrey adds "if a radio station can be sued for broadcasting libellous remarks on a phone-in programme, the same must apply to institutions linked to the Internet."

The statements, which first appeared in 1993 and were reissued from several sites, refer to his departure from the NRC. Internet users in Canada claim that the British physicist baited Canadians by suggesting that theirs is a country of third-rate people doing third-rate work, and thus drew inflammatory responses.

The universities have indicated that they intend to defend any proposed action, despite having paid out compensation in an out-of-court settlement. The Canadian Universities' Reciprocal Insurance Exchange, which is handling the claim, is now demanding a refund. It complains that Godfrey breached the terms of settlement by, ironically, announcing it on the Internet.

Universities tend to agree with Internet user groups that interference with Internet messages is a violation of free expression, and they do not consider themselves responsible for information fed into the network through their terminals.

One university, which cannot be identified for legal reasons, says that any talk of censorship of the Internet conflicts with the ethos of allowing unrestricted freedom of speech. The question of whether a particular message is libellous, the university adds, can be decided only by the courts.

Legal experts are reluctant to speculate on the outcome if Godfrey decides to sue. Nick Braithwaite, a media lawyer with Clifford Chance, a firm of London solicitors, says legislation governing the issue is "hazy and unclear".
In principle, universities are protected by the so-called Innocent Dissemination Act, a piece of legislation designed to safeguard organizations from being sued for defamatory material illegally or unwittingly issued in their name.

But this act could work in favour of both sides. The universities will benefit if the courts decide that the material relating to Godfrey was not defamatory. But Godfrey is counting on the fact that the universities are no longer 'innocent' parties, in the legal sense. "It is not a case of innocent dissemination any more," he says. "The universities know that false information is being put out through their channels, yet they still refuse to take action."

The government, according to Nick Braithwaite, is in the process of reviewing

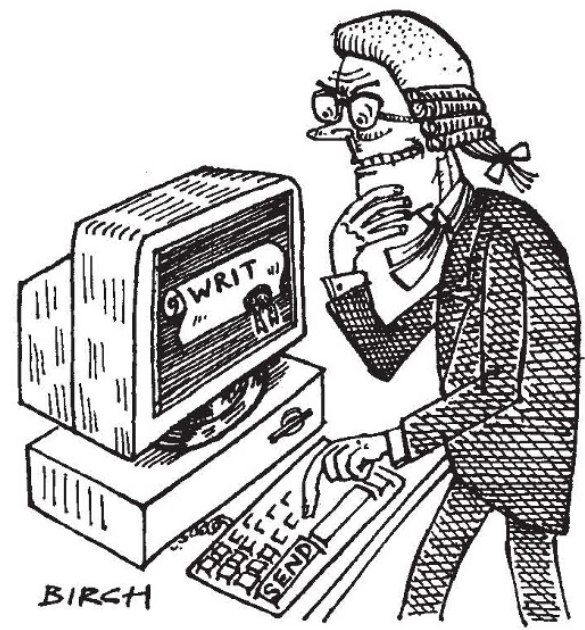

the Innocent Dissemination Act. "It is up to universities to lobby hard and clear up ambiguities," he says.

Meanwhile, they should ensure that they have insurance cover for third-party liability and should issue guidelines warning of the legal pitfalls of bulletin-board use. "People can still have private conversations on the Internet," he said. "But they need to be careful about what they say when using bulletin boards like Usenet and Compuserve."

Godfrey is already pursuing another lawsuit that involves the Internet. This is a case against Phillip Hallam-Baker, a researcher at the European Laboratory for Particle Physics (CERN) in Geneva, which is due to be heard in the high court in London in July. Godfrey, who previously worked at DESY, the German Electron Synchrotron Laboratory, in Hamburg, claims that Hallam-Baker made damaging remarks on Usenet about his professional work. Hallam-Baker says he is ready to defend any action.

David Spurgeon \& Ehsan Masood

\section{Wellcome pledges $\mathbf{\$ 8 0}$ million for population studies}

London. Britain's Wellcome Trust, which last week became the world's richest research foundation, has announced that it is to spend $£ 50$ million (US\$80 million) over the next five years supporting studies of ways to curb unwanted population growth.

Much of this money will be spent outside the United Kingdom, reflecting the trust's efforts to increase the international scope of its activities. Two other enhanced priorities will be its support of studies of researchfunding decisions, and of moves to stimulate the development of new technologies based on the work of Wellcome-supported scientists (see Nature 372, 6; 1995).

The trust's announcement of its new priorities coincided with the formal acceptance last week by the Wellcome Foundation the pharmaceutical company whose shares were vested in the trust on the death of its founder, Henry Wellcome, in 1936 - of a takeover bid by its larger rival, Glaxo.

The bid was successful largely because of the trust's early agreement to sell to Glaxo the 40 per cent of Wellcome shares remaining after two earlier divestitures. It has increased the trust's total 'investment base' to $£ 6.7$ billion, and thus its anticipated annual income by an estimated $£ 50$ million to a sum approaching $£ 300$ million.

But according to Bridget Ogilvie, the director of the Wellcome Trust, its new priorities were in the pipeline before there was any knowledge of the Glaxo bid. "For example, we have been progressing towards the extra funding for population studies for some time," she says, pointing out that one spur was last year's UN Conference on Population in Cairo.

The new directions are also intended to build on developments since the last major sale of Wellcome shares, in 1992. Since then, the trust has concentrated primarily on building up support for research groups in British universities through fellowship schemes, equipment grants and the funding of new buildings.

"We have not yet focused on developing our international portfolios, but this is now our intention," says Ogilvie. Similarly, on the question of technology transfer, she says that the trust is on "a very steep learning curve; we are very keen to get moving".

Meanwhile, the House of Commons Select Committee on Science and Technology published a report on 20 March, based on a meeting with senior officials from Glaxo, the Wellcome Foundation and the Wellcome Trust last month (see Nature 372, 6; 1995), saying that "only time will tell" whether the merged company will be as strong as its chief executive, Sir Richard Sykes, is predicting. 